\title{
Polyommatus fominae Stradomsky, 2005 and P. szabokyi Bálint, 1990 (Lepidoptera: Lycaenidae) - species of hybrid origin of P. icarus (Rottemburg, 1775) and P. icadius (Groum-Grshimanlo, 1890). Part II
}

\author{
Polyommatus fominae Stradomsky, 2005 и P. szabokyi Bálint, 1990 \\ (Lepidoptera: Lycaenidae) - вид гибидного происхожкдения от P. icarus \\ (Rottemburg, 1775) и P. icadius (Groum-Grshimanlo, 1890). Часть II
}

\author{
B.V. Stradomsky ${ }^{1}$, R.V. Yakovlev ${ }^{2,3}$ \\ Б.В. Страдомский ${ }^{1}$, Р.В. Яковлев ${ }^{2,3}$
}

${ }^{1}$ Rostov branch of Russian Entomological Society, PO Box 3318, 344092, Rostov-na-Donu, Russia. E-mail: bvstr@yandex.ru
${ }^{2}$ Altai State University, Lenina 61, 656049 Barnaul, Russia. E-mail: yakovlev_asu@mail.ru
${ }^{3}$ Tomsk State University, Laboratory of Biodiversity and Ecology, Lenin pr. 36, 634050 Tomsk, Russia.
${ }^{1}$ Ростовское отделение Русского энтомологического общества, а/я 3318, 344092, Ростов-на-Дону.
${ }^{2}$ Алтайский государственный университет, пр. Ленина 61, Барнаул, 656049 Россия.
${ }^{3}$ Томский государственный университет, пр. Ленина 36, Барнаул, 634050 Россия.

KEY WORDS: hybrid, fauna, entomology, Lepidoptera, Lycaenidae, Polyommatinae.

КЛЮЧЕВЫЕ СЛОВА: гибрид, фауна, энтомология, Lepidoptera, Lycaenidae, Polyommatinae.

ABSTRACT. Studied specimens of the taxa fominae and szabokyi possess the gene Ef-1a characteristic of $P$. icarus. Specimens previously examined have a genetic mixture of two species: fominae - COI from $P$. icadius, ITS2 and Ef-1a from P. icarus; szabokyi COI and ITS2 from P. icadius, Ef-1a from P. icarus. New data confirm that the taxa fominae and szabokyi are of hybrid origin with the sharing the parental species $P$. icarus and P. icadius.

РЕЗЮМЕ. Изученные экземпляры таксонов fominae и szabokyi обладают геном Ef-1a, характерным для $P$. icarus. Образцы, исследованные ранее , обладают смешанным набором генов: fominae COI от $P$. icadius, ITS2 и Ef-1а от P. icarus; szabokyiCOI и ITS2 от $P$. icadius, Ef-1a от $P$. icarus. Новые данные подтверждают, что таксоны fominae и szabokyi имеют гибридное происхождение от родительских видов P. icarus и P. icadius.

\section{Introduction}

We had previously shown that the taxa Polyommatus fominae Stradomsky, 2005 and P. szabokyi Bálint, 1990 originated as a result of hybridization of the species $P$. icarus (Rottemburg, 1775) and P. icadius (Groum-Grshimaïlo, 1890) [Stradomsky, Yakovlev, 2018]. Hybrid- ization was demonstrated by the presence in specimens of fominae and szabokyi the mitochondrial gene COI, characteristic of $P$. icadius, and nuclear sequence ITS2, characteristic of $P$. icarus. Additionally, in some specimens of the taxon szabokyi, the sequence ITS2 corresponded to $P$. icadius. To clarify the molecular genetic characteristics of taxa fominae and szabokyi, we have also studied the nuclear gene Ef-1a [Cho et al., 1995], which encodes the protein elongation factor 1-alpha in both P. icarus and P. icadius.

\section{Material and methods}

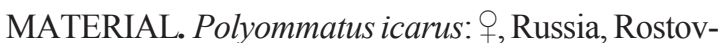
on-Don, Belokalitvensky District, 9.09.2008, B. Stradomsky (voucher ILL283, GenBank accession № MG834540); P. icadius: $\sigma^{7}$, Kyrgyzstan, Ala-too, 02.07.2015, S. Korb (voucher ILL259, GenBank accession № MG834538); $P$. fominae: $\sigma^{7}$, Russia, Karachaj-Cherkesia, Jamagat (1500 m), 25.07.2016, B. Stradomsky (voucher ILL281, GenBank accession № MG834539); P. szabokyi: O', SW Mongolia, Gobi-Altai aimak (1350 m), 62 km SSE Bugat, N slope of Adzh-Bogdo Range, Zoolon-Suuzhijn-Bulag spring, 28.06.2017, R.V. Yakovlev (voucher ILL279, GenBank accession № MG834541). We also used the sequence Ef-1a P. icarus from GenBank № AY496846, voucher NK-00-P562: Kazakhstan, Altai, Oktyabrsk.

How to cite this article: B.V. Stradomsky, R.V. Yakovlev 2018. Polyommatus fominae Stradomsky, 2005 and $P$. szabokyi Bálint, 1990 (Lepidoptera: Lycaenidae) - species of hybrid origin of P. icarus (Rottemburg, 1775) and $P$. icadius (Groum-Grshimaïlo, 1890). Part II// Russian Entomol. J. Vol.27. No.3. P.297-298. doi: 10.15298/rusentj.27.3.11 
We amplified DNA 5' section of the nuclear gene elongation factor 1-alpha (Ef-1a) on the Mastercycler gradient (Eppendorf). The following cycling protocols were used: an initial 4 min denaturation at $95^{\circ} \mathrm{C}$ and 40 cycles of $30 \mathrm{~s}$ denaturation at $95^{\circ} \mathrm{C}, 30 \mathrm{~s}$ annealing at $53^{\circ} \mathrm{C}$ and $60 \mathrm{~s}$ extension at $72^{\circ} \mathrm{C}$.

We used the following PCR primer pairs: forward, 5'- TAC CAT CGA GAA GTT CGA GAA G -3' with reverse, 5'- GCC ACC CCT TGA ACC AGG GCA T 3' [Stradomsky, 2016].

Amplified fragments were separated using an automated sequencing machine (Applied Biosystems 3500).

The analysis of primary nucleotide sequences was made with the help of the application BioEdit Sequence Alignment Editor, version 7.0.5.3 [Hall, 1999].

Ef-1a nucleotide sequences were treated quantitatively using MEGA5 [Tamura et al., 2011] methods Minimum Evolution (ME) and were represented as MEcladograms.

To produced the cladogram, we also used the sequences from GenBank ${ }^{11} \mathrm{KF} 468771$ (voucher ILL155), KF468770 (voucher ILL149), KJ671881 (voucher ILL162), KJ671884 (voucher ILL116), KJ671885 (voucher ILL143), KJ671888 (voucher ILL165) and KJ671889 (voucher ILL145).

\section{Results and Discussion}

The specimen nodes for $P$. icarus and $P$. icadius on the ME-cladogram of gene Ef-1a are sister, but completely independent (Fig. 1) indicating an independent

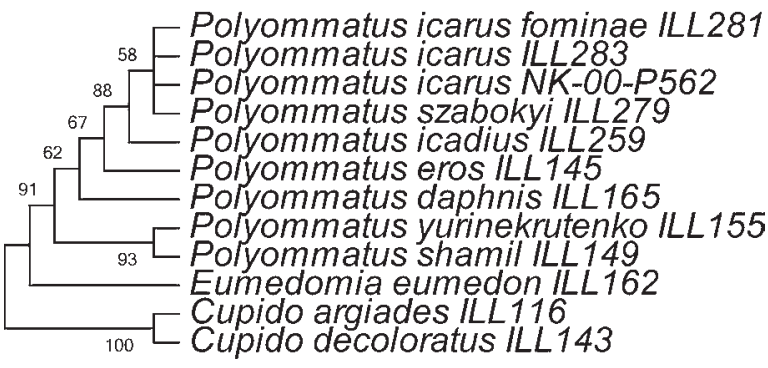

Fig. 1. ME-cladogram for Ef-1a DNA sequences.

Рис. 1. МЕ-кладограмма для ДНК-последовательности Ef-1a. status of these species. Concurrently, the taxa fominae and szabokyi belong uniquely to the clade corresponding to $P$. icarus.

It should be also noted that the studied specimens of fominae and szabokyi had the mitochondrial COI gene characteristic of $P$. icadius. In this case, the nuclear sequence ITS2 in the specimen fominae corresponded to that of P. icarus, and in the specimen szabokyi - to P. icadius [Stradomsky, Yakovlev, 2018]. Thus, both specimens had more and less pronounced mixture of genes of both species: fominae (voucher ILL281) COI from P. icadius, ITS2 and Ef-1a from P. icarus; szabokyi (voucher ILL279) - COI and ITS2 from $P$. icadius, Ef-1a from P. icarus.

Our study provides support that the taxa fominae and szabokyi are of a hybrid origin with the parental contribution of the species $P$. icarus and P. icadius.

ACKNOWLEDGMENTS. The results were obtained within the framework of the state task No. 6.2884.2017/4.6 Ministry of Education and Science of Russian Federation. The authors are grateful to Anna Ustjuzhanina (Tomsk, Russia) and Prof. Boris Kondratieff (Fort Collins, USA) for language improvements.

\section{References}

Cho S., Mitchell A., Regier J.C., Mitter C., Poole R.W., Friedlander T.P., Zhao S. 1995. A highly conserved nuclear gene for lowlevel phylogenetics: elongation factor-1 alpha recovers morphology-based tree for heliothine moths // Molecular Biology and Evolution. Vol.12. No.4. P.650-656.

Hall T.A. 1999. BioEdit: a user-friendly biological sequence alignment editor and analysis program for Windows 95/98/NT // Nucleic Acids Symposium Series. Vol.41. P.95-98.

Stradomsky B.V. 2016. A molecular phylogeny of the subfamily Polyommatinae // Caucasian entomological bulletin. Vol.12. No.1. P.145156.

Stradomsky B.V., Yakovlev R.V., 2018. Polyommatus fominae Stradomsky, 2005 and P. szabokyi Bálint, 1990 (Lepidoptera: Lycaenidae) - species having appeared due to hybridization of P. icarus (Rottemburg, 1775) and P. icadius (Groum-Grshimaïlo, 1890) // Russian Entomological Journal. Vol.27. No.1. P.51-54.

Tamura K., Peterson D., Peterson N., Stecher G., Nei M., Kumar S. 2011. MEGA5: molecular evolutionary genetics analysis using maximum likelihood, evolutionary distance, and maximum parsimony methods // Molecular Biology end Evolution. Vol.28. P. 2731-2739. 